\title{
INDUSTRIAL CHANGE, FINANCIAL SYSTEM AND COHERENT INDUSTRIAL POLICY
}

\author{
Patrizio Bianchi and Sandrine Labory, \\ Department of Economics and Management, University of Ferrara
} Keywords: Financialisation, Industrial Policy, Industrial and
Financial Sectors.

Mots-clés : Financiarisation, politique industrielle, secteurs financiers et industriels.

\section{INTRODUCTION}

The debate on the relationship between the financial and the non-financial sectors of the economy is an old one. Schumpeter (I9II) argued that an efficient and effective financial system has a positive impact on economic growth. Keynes (1930) argued in favour of the importance of the banking sector for economic growth. He suggested that bank credit "is the pavement along which production travels, and the bankers if they knew their duty, would provide the transport facilities to just the extent that is required in order that the productive powers of the community can be employed at their full capacity" (I930, II, p. 220). Keynes (1936) subsequently argued in favour of government control over investment. Robinson claimed that "where enterprise leads, finance follows" (I952, p. 86), so that financial development follows growth.

Recently this debate has experienced renewed interest after the financial crisis, which revealed the extraordinary growth of the financial sector 
over the last 30 years, and the increasing gap between the financial and the real sectors of the economy, a phenomenon which has been called "financialization" (Epstein, 200I; Krippner, 2004; Crotty, 2005).

The period of the extraordinary growth of the financial sector is also a period of important changes in the "real" or industrial sector. Bianchi and Labory $(2006,2010,2013)$ showed that this period is characterised by increasing pressure for structural change due to the necessity for firms to adapt to changing competitive conditions. The competitive context has indeed started to dramatically alter, starting from the crisis of the mass production system and crisis of the large firm, to the diffusion of new production organisational models (for instance automation, Japanese system, as well as industrial districts). From the rg9os onwards industries from the developed countries have been increasingly challenged by new players, especially from emerging countries. Globalisation has increased, in the sense of intensifying trade and FDI worldwide, due to opportunities in new and growing markets and differentials in input costs, eased by new technology such as ICTs.

Industrial policy, in the sense of set of measures aimed at favouring structural changes in productive sectors, have been implemented throughout the entire period starting after World War II and up to today, even in the I990s when even the word should not be mentioned (Bianchi and Labory, 2006). Many scholars have analysed these policies, particularly in Europe (Cohen, 2007; Federico and Foreman-Peck, I999; Bailey and Driffield, 2007), and in Asia (Chang, 2006; Lall, 2006). However, the type of adopted measures have changed, so much so that three phases of the implementation of industrial policy in the period can be identified (Bianchi and Labory, 2006, 20II; Labory, 2006). The first phase is that of interventionist and selective industrial policy, characterised by direct intervention of the government in markets, the government often being producer, via state-ownership. Such policies tended to favour "national champions" or consisted in "picking the winner". In Europe, this was also accompanied by a lax implementation of competition policy and regulation of the "commandand-control" type. 'This type of policy started to show inefficiencies in the

I Command-and-control is defined in contrast to incentive-based regulation: the former imposes the behaviour on agents (essentially through standards) while the latter induces agents to adopt the right behaviour, such as a tax on pollution which 
I970s, where state-owned firms tended to have low productivity or made wrong strategic choices due to the influence of other interests than the purely profit-maximising interests of the firm (particularly government interests such as preserving employment in recessions).

The second period is that of the I980s and I99os essentially, and can be called the liberal years. Industrial policy of the past was abandoned because of its inefficiencies. However, industrial policies in the sense of policies promoting structural changes were still implemented, under different names: competitiveness or enterprise policy. Competition policy was implemented more stringently, regulation became incentive-based, and measures to favour structural changes were preferably horizontal: implemented across all sectors of the economy rather than sector or firm-specific. Preferred measures include policies for SMEs, favouring their networking and supporting entrepreneurship by simplifying firm creation procedures, providing training, better access to finance; innovation policies favouring RED collaborative programmes, financing research projects on important - generic - technologies, and then favouring the interaction between universities and industries for technological transfer. The aim of industrial policy in that period was to provide the conditions for the competitiveness of industry. In Europe, these objectives were included in the Maastricht Treaty after the Bangemann Report, which proposes this new industrial policy, calling it competitiveness policy, where the state is a pioneer and catalyst of changes (Bangemann, I990).

The focus on providing the conditions for the competitiveness of firms and the development of sectors continues in the third period of industrial policy. This essentially starts at the turn of the new century, when industrial firms, concerned with de-industrialisation, increasingly call for industrial policy. In Europe this culminates in the declaration of two heads of states, Jacques Chirac and Gerhard Schroeder, in 2003, proposing industrial policy to end de-industrialisation and respond to competitiveness challenges of the new century.

Like in the liberal years, competition policy is still stringently applied, regulation is rather incentive-based, measures and actions are primarily

induces agents to change behaviour and adopt pollution-abating strategies because it becomes utility-maximising. 
horizontal and aim at providing the conditions for competitiveness and development; however, vertical measures in the sense of measures specific to sectors are also envisaged if necessary to reach the objectives (European Commission, 2003, 2006, 2010).

Regarding the financial sector, the liberal years are also years of important financial deregulation. A strong wave of hostile takeovers took place in the I980s, followed by important changes in corporate governance in the 1990s: institutional shareholders strengthened. In Europe, various steps were taken in the I9gos to progressively integrate the European financial market in view of the adoption of the euro in the European Monetary Union. These years were also characterised by an increasing transfer of earnings from non-financial corporations to financial markets in the forms of interest and dividend payments and stock buybacks. Top managers increasingly focused on the short-value of the firms' shares rather than long-term objectives of investment and growth, thereby diffusing "short-termism" among management of non-financial corporations.

The financial sector substantially developed but this was generally seen as part of the tertiarisation of the economy whereby later stages of economic development industrialisation (the growing importance of the manufacturing or secondary sector) would leave the space to the development of the service sector (the tertiary sector becoming relatively more important of the three sector categories). Thus the financial sector developed a lot, encouraged by governments, which saw this as a normal tertiarisation of the economy that would create jobs in the financial sector for those who lost jobs in declining industries.

Until the financial crisis exploded and revealed the exaggerated growth of the financial sector relative to the real sector, and the financialization of firms' strategies in both the financial (banks) and non-financial sectors.

In fact, the financial sector grew so big and made so high profits that the question was raised as to whether it impeded non-financial structural change as a result, by drawing away not only money, but also human capital from the real sector, since many engineers preferred working in the financial sector to get higher wages than in industry. 
The aim of this paper is to discuss the effects of financialisation on the real sector. The evidence on financial sector development and financialisation is highlighted on the basis of a literature review in the second section. The third section examines the effects of financialisation and excessive financial sector growth on the real sector. The fourth section argues that the return of industrial policy in the new century has been characterised by measures addressing the negative effects of financialisation on firms. The new industrial policy of the 2Ist century does not represent a return to selective and interventionist policies of the ig6os and I970s but consists in broad policy sets aiming at favouring structural changes and industrial development. The conclusions are that these broad sets should include the financial sector to ensure that finance is dedicated to financing the real economy rather than to speculative activities.

\section{EVIDENCE ON THE EXAGGERATED GROWTH OF THE FINANCIAL SECTOR}

The financial system has a crucial role in stimulating economic growth and development. There is consensus in the literature on the fact the financial systems contribute to economic efficiency, a better allocation of productive capital, and increase long-term growth (Levine, 2005, for a review).

However, more dynamic and larger financial industries are also associated with more frequent financial shocks and higher risk. The damages of the 2008 financial crisis illustrate this point.

The financial sector has grown enormously in the last decades. Data abound to support this stylised fact. In the US, the number of employees in the financial sector has more than doubled between 1970 and 2006 (Figure I). The banking sector's assets in the UK was 50\% of GDP in the I970s, and $300 \%$ in $2000,550 \%$ in 2007 . This trend is explained by the fact that the US and the UK are world-wide financial centres, by the large rise in global savings in the period, especially from emerging countries and the rise in productivity driving rising profits. 
Figure 1. Employees in the US financial sector, thousands

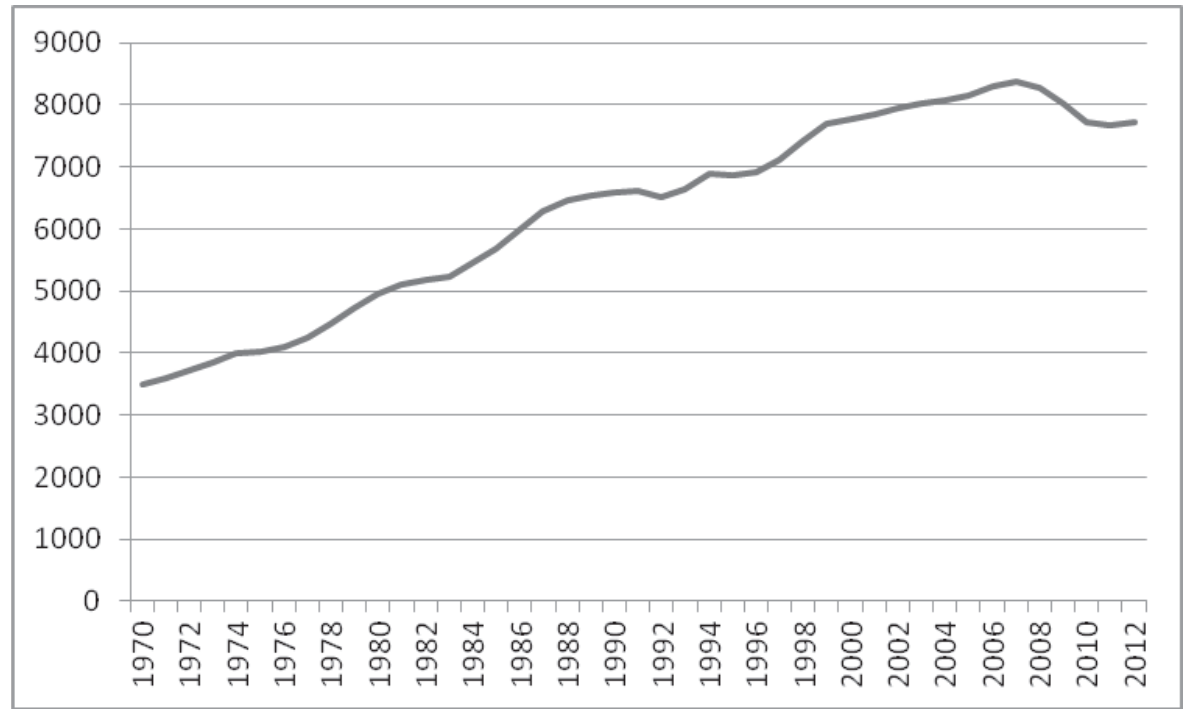

Source: US Bureau of Labor Statistics (data downloaded www.bls.gov).

More generally in the world, data on market capitalisation and the total value o stock trades give an indication of the huge growth of the financial sector (Figures 2 and 3 ).

Figure 2. Market Capitalisation of listed domestic companies (USD trillions)

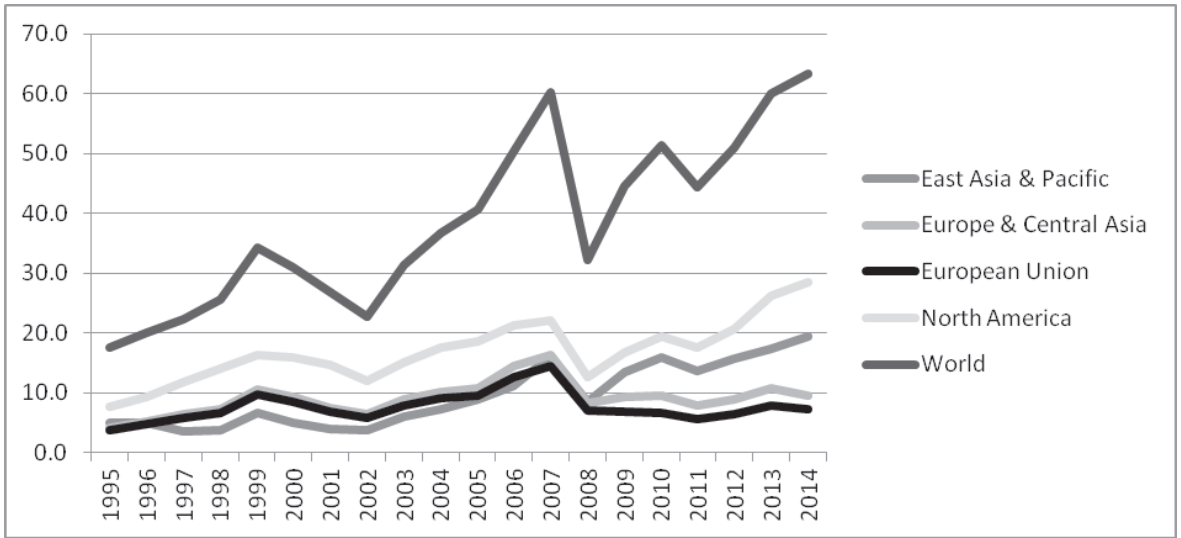

Source: World Bank at beta.data.worldbank.org. 
Figure 3. Stocks traded (\% of GDP)

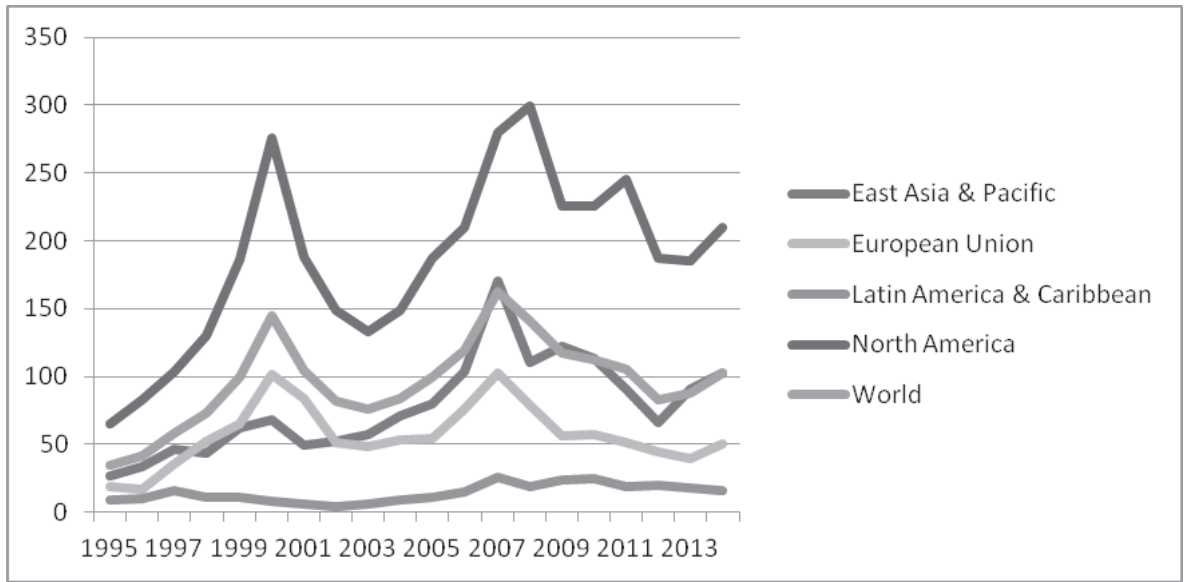

Source: World Bank at beta.data.worldbank.org.

The role of the financial sector is to identify productive opportunities and drive resources to these opportunities so that they can grow. During the last decades the US financial market has helped the development of new sectors with the relatively easy availability of venture capital or other capital for business start-ups. Florida and Kenney (1988) argued in favour of the positive role of venture capitalists in innovation in the USA. Kortum and Lerner (2000) showed that venture capital have accounted for about $8 \%$ of patented innovations in the period 1965 to 1992 . Venture capital has increased substantially in the USA after a 1979 law favouring them. In Europe, the development of venture capital has been more recent, and governments have provided this type of capital when private venture capital was lacking. Da Rin and Penas (2007) showed that venture capital has had a positive effect on innovation in Dutch firms in the late-I9gos and early years 2000 , by inducing them to strengthen both their absorptive capacity and their in-house RED efforts. In contrast, it appears that governmentsponsored venture capital has positive effects on business as long as the provided funds remain relatively low, while the effects become negative as the amount of government-sponsored venture funds rise (non-monotonic relationship highlighted by Brander et al., 20Io, looking at effects on the likelihood of exit of funded firms).

However, too big financial markets can produce bubbles, excessive risktaking and over-leveraging. 
The issue of the optimal size of the financial sector is not resolved. Research shows that there are non-linearities in the relation between the size of the financial markets and economic growth. The relationship is positive up to some level, but for high levels of the size of financial markets the relationship starts to weaken (Cecchetti and Kharroubi, 2012, 2015; Rioja-Valev, 2004). "That is, at low levels, a larger financial system goes hand in hand with higher productivity growth. But there comes a point - one that many advanced economies passed long ago where more banking and more credit are associated with lower growth" (Cecchetti and Kharroubi, 2012, p. I). In addition, these authors find that faster growth in finance has a negative impact on aggregate productivity, basing their analysis on a sample of 50 advanced and emerging economies over the period I980 to 2009 and using different measures of financial sector growth.

There is also evidence that the growth of the financial sector has largely been self-referential, as the rise in claims and obligations has mainly arisen between financial firms. For instance Bartiloro and Di Iasio (20I2) argue that non-financial corporations have only partially taken advantage of the large increase in the financial sector in the last 15 years. They analyse the way in which differences in financial systems are reflected in firms' capital structure. Comparing France, Germany, Italy, Spain, the UK and the US, they show that all countries saw their stock exchanges substantially increase, except for Germany and Italy which financial systems largely remain bank-based. However, this rise in the financial sector is essentially due to a growth in the financial intermediaries (namely banks, central bank and market mutual funds), which asset holdings have substantially increased, although to a lesser extent in the US. The liability structure of financial intermediaries has also changed in important ways. Retail deposits of households have been replaced by shares and other equity. The relevance of funding by means of short-term loans has thus substantially increased, implying a higher interconnection of the financial system. The financial systems of these different countries therefore appears to have become more vulnerable because more intertwined and more reliant on short-term instruments. Non-financial firms do not appear to have drawn any substantial benefits from these changes since the rise in inter-bank deposits or rising securities comes at the expense of long-term loans to firms. 
The growing importance of the financial sector is also discussed in the "financialization" debate. The concept of financialization of firms or of the economy has indeed appeared in the economic and political debates with different but related meanings. First, the concept of financialization of the economy refers to the large increase in the absolute and relative value of financial transactions in the last decades in a context of financial deregulation (Krippner, 2004; Epstein, 2006; Palley, 2007). According to Epstein (200I, p. I), financialization refers to "the increasing importance of financial markets, financial motives, financial institutions, and financial elites in the operation of the economy and its governing institutions, both at the national and international levels". Power et al. (2003) show that this phenomenon seems to have affected most OECD countries. The neo-liberal policies of the I980s and the I990s are generally presented as the main driver of this financialization (Palley, 2007; Krippner, 20II). The effects of this phenomenon on the real sector are discussed in more details in the next section.

The measures taken after the financial crisis have had a small impact on the financial sector: the situation today tends to be business as usual, the "usual" part being the pre-crisis situation. Leveraging is getting back to pre-crisis levels, and many investors are increasingly indebted. In the US, total corporate-bond debt is up 59\% relative to 2007 ; corporate debts have doubled since i999. Corporate leverage, that measures risk by comparing debt to earnings, has returned to pre-crisis levels and more. However, households' indebtedness has substantially reduced, and the situation of banks is much healthier than pre-crisis. Measures taken after the crisis have aimed at increasing the financial sector's stability, by reducing the riskiness of the whole system via macro-prudential supervision.

The real economy needs the financial sector for its long-term investments. However, financial markets tend to generate excesses. Schumpeter was the view that economic cycles were efficient in regulating the economy: economic growth arises in boom phases, followed by recessions that are useful to eliminate unproductive projects. Minsky (1986) and Kindleberger (1978) argued in contrast that cycles are not efficient in that booms tend to favour speculative behaviours and excessive debt that ultimately lead to financial crises. Hence policy-makers goal in regulating financial markets should be to avoid excessive risk while ensuring contribution to growth. 
Epstein and Crotty (2013) estimated that 60 to $70 \%$ of large investment banks income in the height of the bubble derived from trading activities, related to speculation.

\section{CONSEQUENCES FOR THE REAL SECTOR}

The excessive growth of the financial sector has four consequences on the real sector. First, resources are drawn away from the real sector, leading to a lack of availability of financial resources for long-term investments. The structure and operation of the financial markets have changed due to financial innovation and deregulation, altering the menu of financial assets and liabilities as mentioned in the previous section. Post-Keynesian lines of inquiry have stressed the negative effects in particular of higher indebtedness, higher profit shares, shifts in income away from workers and lower retained profits of companies on long-run growth (Palley, 2007).

The effects of financialization on the capital accumulation process has been explored. Thus Crotty (2005) examined the increasing investments made by non-financial corporations in financial assets rather than productive ones. Duménil and Lévy (2004) provided evidence of growing interest and dividend payments to financial markets, leading to smaller amounts of funds for real investment. Aglietta and Breton (200I) made the same point and argued that an active market for corporate control pushes firms to boost their share price through dividend payouts or stock buybacks and, as a consequence, the share of earnings devoted to financing growth is reduced.

Second, timing becomes too focused on the short-term versus the longterm. Companies' managers have increasingly been induced to put shortterm financial results as the priority. Cash flow, generated by productive and commercial activities are increasingly used for financial investments, namely investments in financial derivatives, re-purchase of own stocks and financing of mergers and acquisitions. The goal of shareholder value maximisation becomes the main objective of many corporations. This means that companies essentially work in the short-term at the expense of long-term investments. A number of management studies based on surveys of firms' managers have shown evidence of this shift in behaviour (see Salento et al., 2013, for a review). 
Short-termism is also stressed by Lazonick (2010), who shows that $438 \mathrm{com}$ panies of the SEP500 listed in 1997 spent 2.7 trillion dollars in own stock repurchasing and distributed about 2 trillion dollars in dividends. Thus resources were shifted from the industrial sphere to the financial one. In addition, many non-financial firms have started to offer financial activities as well as industrial products, initially as a strategy to help sales of industrial products. Thus for instance the automobile producers provide financial services to ease the purchase of cars for their customers. This could be seen as a useful practice to help sales, but the problem is that these financial activities have tended to become more profitable than the industrial ones for many firms, implying that in the end the production of goods becomes instrumental to the sale of financial services. For instance, the financial division General Motors Acceptance Corporation generated about $80 \%$ of the earnings of the whole General Motors Group (Salento et al., 2013). This contributes to the focus on shareholder value maximisation at the expense of long-term investments, namely short-termism of management.

Third, not only financial resources but also intangible assets such as human resources are drawn away from the real to the financial sector. The evidence that the financial sector lures high-skilled people who could provide the technical and engineering skills needed in the financial sector illustrates this point.

Thus Philippon and Reshef (2007) show that the financial sector has been hiring more and more skilled individuals since the early-I98os, at a higher rate than the rest of the private sector. Wages have grown much faster in the financial sector than in the other sectors since the late-I970s onwards. The hour-share of college graduates increased from I3\% to 30\% in the private sector between 1967 and 2005 , and from $18 \%$ to $47.5 \%$ in the financial sector. In addition, the fastest growing occupations in the financial sector are related to trading of financial assets and to the use of computers and mathematics, at the expense of jobs involving more routine tasks.

Cecchetti and Kharroubi (20I5) confirm this point by showing that financial sector growth indeed crowds out the real sector, drawing away highlyskilled labour from RED intensive sectors and sectors which depend on external finance for their investments. More specifically, they find that a RED intensive sectors in countries with financial boom grow about 
I.9-2.9\% a year slower that low RED intensive sector in countries with slow financial growth.

Fourth, the territorial dimension of activities shrinks. Financial activities are intangible and not linked to territories. When firms are essentially governed by short-term financial interests the advantages of rooting their activities in territories where they can take advantage of the social capital created and maintained locally become secondary relative to short-term financial imperatives. More importantly, the financial sector gets increasing distance with important agents of industrial development, namely SMEs. The evidence has indeed been that SMEs have been particularly affected by the financial crisis in terms of access to finance and investment opportunities (EIB, 20I3). The restructuring in the banking sector in the last decades has been characterised by mergers and acquisitions leading to the creation of large banks and the reduction in small local banks, which have constituted the primary channel for SMEs relationships with the financial sector. Industrial development is a bottomup process, whereby firms are created in specific territories, where and when they find appropriate social and institutional networks. The economic geography literature has stressed that point (see Boschma, 20I5, for a review). In addition, current industrial structural changes seem to lead to an increasing importance of territories, which have to mobilise skills and knowledge in order to specialise in specific tasks and strategic phases of production processes in global value chains. For this purpose, regional industrial policy appears to have an important role (Bristow and Healy, 20I4; Bianchi and Labory, 20I6a). This contrasts with the financial sector, which is global and not place-based.

\section{NEW INDUSTRIAL POLICIES AT THE TURN OF THE CENTURY}

Europe is today experiencing an investment crisis. According to the EIB, in 20I2, investment levels are about 17 per cent below their peak in 2008. Investment is particularly low in the most crisis-hit old Member States Greece, Ireland, Portugal and Spain. Even before the crisis investment in non-financial activities was low, due to low expected returns compared to financial assets. 
Government investment in percentage of GDP was rather stable already before the crisis, although it increased in nominal terms (Figure 4).

Figure 4. Gross fixed capital formation by the government, 1995 to 2012

In EUR bn

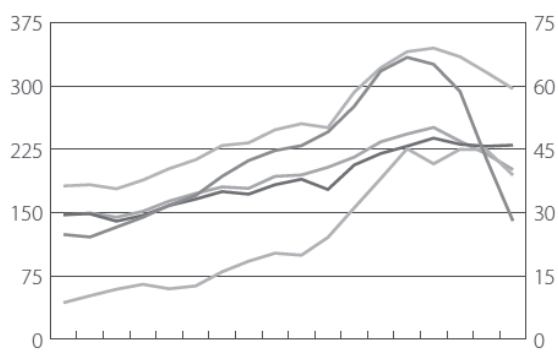

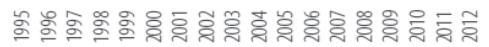

- OMS, excl. cohesion countries (left axis)

- OMC (right axis)

- NMS (right axis)

EU-27 (left axis)

EA-17 (left axis)

Source: Eurostat

Note: $\quad O M S=$ Old Member States excluding crisis countries (AT, BE, DE, DK, FI, FR, IT, LU, NL, SE, UK) $O M C=$ Old Member States in Crisis (EL, ES, IE, PT)

$N M S=$ New Member States (BG, CY, CZ, EE, HU, LV, LT, MT, PL, RO, SI, SK)

Source: EIB (2013, p. I44).

In 2007, immediately before the crisis, among the largest EU old members, investment rates were higher than the EU average in Spain and Italy, below the EU average in France, the UK and Germany.

Figure 5. Ratio of gross fixed capital formation to gross value added in 2007

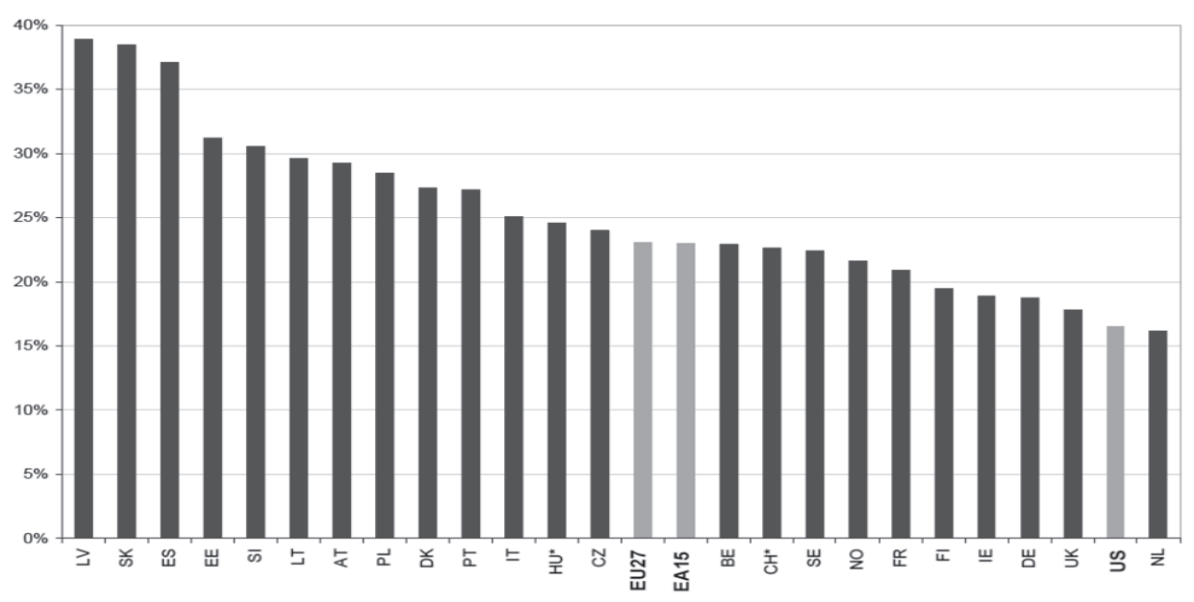


(Bianchi and Labory, 20I6b). Intangible assets are defined as claims to future benefits, which do not have a financial or physical embodiment, such as human capital, innovation, organisational and social capital. In the EU and the OECD in particular, intangible assets such as human capital and innovation have been at the centre of policy makers' interests since the beginning of the years 2000, because they appear to be the key determinants of knowledge creation and entrepreneurship, hence of competitiveness and growth (European Commission, 2000a, b; 200Ia, b; OECD, 200Ia, b; 2003a, b).

Industrial policy strategies proposed at the turn of the new century therefore emphasise the importance of knowledge creation, hence innovation policy, as well as policies towards education and training, to raise the skills in the labour force. Labory (2006) also stressed that industrial policy implemented in the last Io to 15 years in various countries, including Europe, but also the USA and Japan, have stressed the importance of bottom-up processes, namely industrial development starting in specific poles or territories where particular knowledge and competencies concentrate. Hence the policy of cluster, especially high tech ones, is another aspect of the new industrial policy.

For instance a report of the European Cluster Observatory (Oxford Research, 2008) identified 69 national cluster policy programmes, together with regional programmes in 17 European countries. The OECD published different studies on clusters and their role in regional development, particularly in innovation that clusters introduce in the economic system (Roeland and den Hertog, I999; OCSE, 2007). In their Global Cluster Initiative survey, Sölvell et al. (2003) surveyed 509 cluster initiatives realised worldwide; more than half of these were in Europe, and most concerned new or high tech sectors. Clusters are systems of firms, especially SMEs, embedded in territories, standing in contrast with the global and place-less financial sector outlined in the last section.

Another point stressed has been the importance of the dialogue between the government, business and education and research institutions such as universities in the definition of appropriate industrial strategies. The governance of industrial policy has to be multilevel and participative (Bianchi and Labory, 20I6a). Participative means that industrial policy is designed taking account of the views of the different stakeholders involved in the 
industrial development process: business, worker representatives, education institutions, and so on. This has been the case even at European level when business pushed in the late-I980s for the completion of the single market as a policy to promote growth and jobs. However, industrial development is a bottom-process and firm creation primarily starts at the local level, when a small firm is created and develops thanks to a favourable environment. Even in globalisation and the diffusion of global value chains as production processes, territories have to specialise in specific tasks (Bianchi and Labory, 20II). Consequently the governance process of industrial policy has to be multilevel, with rules and specific programmes defined at national level but also complemented by regional industrial policy (Bianchi and Labory, 20r6a).

These aspects have increasingly been stressed even in recent years, both at national and international levels: the OECD (Warwick, 2013) and many other organisations such as the Inter American Development Bank (IDB, 20I4) for instance have been advocating these aspects of industrial policy.

Industrial policies are now broadly defined, as policies aimed at favouring structural changes in productive sectors. They are no longer of the "picking the winner" or "national champion" type, in the sense of departing from the policies implemented in the first phase mentioned in this paper's introduction, where governments directly intervene in markets to promote specific firms or industries and often be producers, via state-ownership. Rather, they aim at providing the conditions for the competitiveness firms and industries, favouring specific growth path, such as particularly green growth paths (Rodrik, 20I4).

Even in the UK the debate on industrial policy has been vivid (0'Sullivan et al., 20I3; Bailey et al., 20I5). The idea is that governments can have a role in favouring comparative advantages of countries and "re-balancing" the economy when certain sectors are underdeveloped, particularly high tech and/or green ones.

Section 3 has highlighted the implications of the high growth of the financial sector on the real sector. It was argued that the financial sector was likely to draw away resources from the real sector, which could explain the investment crisis in Europe arising even prior to the crisis. Shorttermism was a second consequence, contrasting with industrial policy, 
which has long-term horizon, aiming at favouring structural changes arising through long-term investments and long-term evolutionary processes whereby new knowledge is created and diffuse in the economy, thanks to new human capital which skills take time to adjust, especially when highly-skilled workers are lured by the financial sector and not the real one (third consequence).

Fourth, industrial development has been increasingly emphasised as a bottom-up process, whereby the territory and its capacity to create new firms and develop SMEs are key in spurring industrial development and growth. This is in contrast with the financialisation trends, which imply shrinking territorial dimension. Yet the importance of industrial policy at lower levels than the national one, especially the regional one, has been increasingly stressed, for instance in Italy (Cappellin et al., 20I4).

\section{CONCLUDING REMARKS}

The European Commission has proposed with the 2020 Strategy a vision of industrial development leading to growth and jobs, based on environmental sustainability as well as social inclusion. An integrated industrial policy, comprising not only actions directly aimed at industry such as REDD subsidies, but also coherent social and educational policies (to favour access to the labour market thanks to the training in appropriate skills and social actions to help participation in the labour force, from health to child care, transport and housing), trade policy and competition policy. The discussion above leads to propose a broad view of productive sectors that would include financial sectors, and policies towards the financial sectors that would provide incentive for financial institutions to focus their financing activities on the real sector rather than on speculative activities.

For this purpose, Sawyer (2014) proposes four reforms of the financial sector that would support an industrial strategy. First, financial transaction taxes would help reduce speculation in the financial sector and therefore re-orientate finance towards long-term productive investments. Second, a separation between commercial and investment banking would help refocus the financial sector on the savings-investment linkages. Third, 
a restructuring of the banking sector should be promoted to discourage banking activities in derivatives and other financial assets and to favour the channelling of savings to productive investments. Fourth, guided lending would ensure that specific shares of banks' lending would flow to specific sectors, such as green sectors. This could also be favoured, according to Sawyer, by the creation of state sponsored development bank, such as a Green Investment Bank: "note that as with the European Investment Bank any lending by governments can be leveraged through direct borrowing by the development bank, and that such borrowing (as is the case with the European Investment Bank) does not appear on the balance sheets of any national or EU organisation" (Sawyer, 20I4, p. 22).

Manufacturing renaissance has been advocated since the McKinsey Report of 20I2, meaning that tertiarisation is not the panacea to all economic problems, but industrial sectors are also important for economic development. The European Commission hence published a communication on industrial policy for manufacturing renaissance in 2014 (European Commission, 2014). However, the discussion in this paper shows that Manufacturing renaissance also means a rebalancing of productive sectors, including a financial sector returning to its primary function of provider of finance to real and long-term activities.

\section{REFERENCES}

AGLIETTA, M., BRETON, R. (200I), “Financial systems, corporate control and capital accumulation", Economy and Society, 30(4).

BAILEY, D., COWLING, K., TOMLINSON, P. (2015), New Perspectives on industrial Policy for a Modern Britain, Oxford, Oxford University Press.

BAILEY D., DRIFFIELD N. (2007), "Industrial Policy, FDI and employment: still a 'missing strategy'", Journal of Industry, Competition and Trade, 7(3), I89-2II.

BARTILORO, L., DI IASIO, G. (20I2), "Financial Sector Dynamic and Firm Capital Structure", in F. De Bonis, A. R. Pozzolo (eds.), The Financial Systems of Industrial Countries, Berlin, Springer-Verlag.

BIANCHI, P., LABORY, S. (2016a), “The Institutional Framework of Industrial Policy", in P. Bianchi, S. Labory, Towards a New Industrial Policy, Milano, McGraw Hill Education, chapter 8.

BIANCHI, P., LABORY, S. (2016b), “The Institutional Framework of Industrial Policy", in P. Bianchi, S. Labory, Towards a New Industrial Policy, Milano, McGraw Hill Education, chapter 2. 
BIANCHI, P., LABORY, S. (2013), "Structural Transformations in Industries and Filieres", Revue d'économie industrielle, 144, 173-195.

BIANCHI, P., LABORY, S. (2OII), Industrial Policy after the Crisis. Seizing the Future, Cheltenham, Edward Elgar.

BIANCHI, P., LABORY, S. (20I0), "Economic Crisis and Industrial Policy", Revue d'économie industrielle, 129-130, 30I-326.

BIANCHI, P., LABORY, S. (2006), “From old industrial policy to new industrial development policies: an Introduction" in P. Bianchi, S. Labory (eds.), International Handbook of Industrial Policy, Cheltenham, Edward Elgar, 3-27.

BOSCHMA, R. (2015), "Towards and Evolutionary perspective on regional resilience", Regional Studies, 49(5), 733-75I.

BRANDER, J. A., DU, Q., HELLMANN, T. F. (20I0), “The effects of government-sponsored venture capital: international evidence", NBER Working Paper, No. I652I.

BRISTOW, G., HEALY, A. (20I4), "Regional Resilience: An Agency Perspective”, Regional Studies, 48(5), 923-935.

CAPPELlin, E., MARELli, E., RULlAni, A., STERlaCCHINI, A. (eds.), Crescita, investimenti e territorio: il ruolo delle politiche industriali e regionali, Website "Scienze regionali", ebook 20I4.I.

CECCHETTI, S. G., KHARROUBI, E. (20I2), "Reassessing the impact of finance on growth", BIS Working Paper, No. 38I.

CECCHETTI, S. G., KHARROUBI, E. (2015), “Why does financial sector growth crowd out real economic growth", BIS Working Paper, No. 38I.

CHANG, H.-J. (2006), "Industrial Policy in East Asia. Lessons for Europe", EIB Working Papers II/2006, European Investment Bank, Economics Department.

COHEN, E. (2007), "Industrial Policies in France: the Old and the New", Journal of Industry, Competition and Trade, 7(3), 213-227.

CROTTY, J. (2005), “The Neoliberal Paradox: The Impact of Destructive Product Market Competition and 'Modern' Financial Markets on Nonfinancial Corporation Performance in the Neoliberal Era", in G. Epstein (ed.), Financialization and the World Economy, Northampton, MA: Edward Elgar.

DA RIN, M., PENAS, M. F. (2007), “The effect of venture capital on innovation strategies", NBER Working Paper, No. 13636.

DUMÉNIL, G., LÉVY, D. (2004), Capital Resurgent, Cambridge, MA, Harvard University Press.

EPSTEIN, G., CROTTY, J. (2013), “How big is too big? On the social efficiency of the financial sector in the US", Political Economy Research Institute, WP No. 3гзг.

EPSTEIN, G. (ED.) (2006), Financialization and the World Economy, Cheltenham, Edward Elgar.

EPSTEIN, G. (200I), “Financialization, Rentier Interests, and Central Bank Policy”, manuscript, Department of Economics, University of Massachusetts, Amherst, MA, December.

EUROPEAN COMMISSION (I990), "Industrial policy in an open and competitive environment", (Bangemann Memorandum), Working Paper, I4 December, Brussels.

EUROPEAN COMMISSION (2000a), "Innovation in a Knowledge-driven Economy", Communication from the Commission to the Council and the European Parliament, $\mathrm{COM}(2000) 567$ final - 20.09.2000. 
EUROPEAN COMMISSION (200ob), “Benchmarking Enterprise Policy. First Results from the Scoreboard", Commission Staff Working Document, SEC (2000) I84I, Bruxelles.

EUROPEAN COMMISSION (2001a), "Statistic on Science and Technology in Europe", Bruxelles.

EUROPEAN COMMISSION (200Ib), "European Competitiveness Report", Luxembourg.

EUROPEAN COMMISSION (20I4), "For a European Industrial Renaissance", COM(20I4) oI4 Final.

EUROPEAN INVESTMENT BANK (EIB) (2013), Investment and Investment Finance in Europe, Luxembourg, EIB.

FEDERICO, G., FOREMAN-PECK, J. (1999), European industrial policy. The Twentieth century experience, Oxford, Oxford University Press.

FLORIDA, R. L., KENNEY, M. (I988), "Venture capital-financed innovation and technological change in the USA", Research Policy, 17, II9-I37.

IDB (20I4), Rethinking productive Development, Washington, Inter American Development Bank.

KEYNES, J. M. (1936), A General Theory of Employment, Interest and Money, London, Macmillan.

KEYNES, J. M. (1930), A Treatise on Money, New York, Harcourt, Brace and Co.

KINDLEBERGER, C. (1978), Manias, panics and crashes: a history of financial crises, London, Palgrave Macmillan.

KORTUM, S., LERNER, J. (2000), "Assessing the contribution of venture capital to innovation", Rand Journal of Economics, 31(4), 674-692.

KRIPPNER, G. (2OII), Capitalizing on crisis. The political origins of the rise of finance, Harvard, Harvard University Press.

KRIPPNER, G. (2005), "The Financialization of the American Economy", Socio-Economic Review, 3(2), 173-208.

LABORY, S. (2006), “La politica industriale in un'economia aperta e basta sulla conoscenza", L'Industria, 2, 255-28I.

LALL, S. (2006), "Industrial policy in developing countries: what can we learn from East Asia?", in P. Bianchi, S. Labory (eds.), International Handbook of Industrial Policy, Cheltenham, Edward Elgar, 79-97.

LAZONICK, W., O'SULLIVAN, M. (2000), “Maximizing Shareholder Value: A New Ideology for Corporate Governance", Economy and Society, 29(I), I3-35.

LEVINE, R. (2005), "Finance and Growth: Theory and Evidence", in P. Aghion, S. N. Durlauf (eds.), Handbook of Economic Growth, vol. IA, chapter 12.

MCKINSEY GLOBAL INSTITUTE (2012), "Debt and deleveraging: uneven progress on the path to growth".

MINSKY, H. (1986), Stabilizing an unstable economy, New Haven, Yale University Press.

OECD (2001a), Beyond the Hype. The OECD Growth Project, Paris, OECD.

OECD (20oIb), "Intangible Investments, Growth and Policy. STI Directorate", DSTI/IND (200I) 5 (September).

OECD (2003a), The Policy Agenda for Growth. An Overview of the Sources of Economic Growth in OECD Countries, Paris, OECD.

OECD (2003b), The Sources of Economic Growth in OECD Countries, Paris, OECD.

OCSE (2007), Competitive Regional Clusters. National Policy Approaches, OECD Review of Regional Innovation, Paris, OECD. 
O'SUlLIVAN, E., ANDREONI, A., LÓPEZ-GÓMEZ, C., GREGORY, M. (2013), “What is new in new industrial policy? A manufacturing system perspective", Oxford Review of Economic Policy, 29(2), 432-462.

OXFORD RESEARCH AS (2008), "Cluster Policy in Europe - A Brief Summary of Cluster Policy in 3г European Countries", Report of the Europe INNOVA Cluster Mapping Project, Bruxelles.

PALlEY, T. I. (2007), "Financialization: what it is and why it matters", The Levy Economics Institute, WP No. 525, New York.

POWER, D., EPSTEIN, G., ABRENA, M. (2003), “Trends in rentier income share in OECD countries, I960-2000", University of Massachussets Amherst, Political Economy Research Institute, Working Paper No. 58a.

RIOJA, F., VALEV, N. (2004), "Does one size fits all? A re-examination of the financegrowth relationship", Journal of Development Economics, 74, 429-447.

ROBINSON, J. (1952), "The Generalization of the General Theory", in The Rate of Interest and Other Essays, London, Macmillan, 67-I42.

RODRIK, D. (20I4), “Green Industrial Policy", Oxford Review of Economic Policy, 30(3), 469-49r.

ROELAND, T. J. A., DEN HERTOG, P. (1999), “Cluster analysis and cluster-based policy making in OECD countries: an introduction to the theme", in OECD (ed.), Boosting Innovation. The Cluster Approach, Paris, OECD, 9-23.

SALENTO, A., MASINO, G., BERDICCHIA, D. (2013), "Financialization and organisational changes in multinational enterprises", Revue d'économie industrielle, 144.

SAWYER M. (20I4), "Finance and Industrial Policy", FESSUD Working Paper Series, No. 3I.

SChUmpeteR, J. (I934 [igri]), The Theory of Economic Development, Cambridge, Mass., Harvard University Press.

SÖLVELL Ö., LINDQVIST G., KETELS C. (2003), The Cluster Initiative Greenbook, Gothenburg, Ivory Tower AB.

WARWICK, K. (2013), Beyond industrial policy. Emerging issues and new trends, Paris, OECD. 